\title{
Erratum to: Ukraine's foreign trade: responses to global challenges
}

Svitlana Radziyevska ${ }^{1}$, Ivan Us ${ }^{2}$

${ }^{1}$ National Academy of Management, 15 Ushynskoho St., Kyiv, 03151, Ukraine

${ }^{2}$ The National Institute for Strategic Studies, 7-a Pyrogova St., Kyiv, 01030, Ukraine

Original article: SHS Web of Conferences 107, 04001 (2021), https://doi.org/10.1051/shsconf/202110704001

The last name of the first author in the article should be replaced by the following:

Radziyevska 